\title{
Toxic Cyanobacteria in Four Brazilian Water Supply Reservoirs
}

\author{
Viviane Piccin-Santos ${ }^{1,2}$, Maria do Carmo Bittencourt-Oliveira ${ }^{1,2}$ \\ ${ }^{1}$ Department of Biological Sciences, Luiz de Queiroz College of Agriculture, University of São Paulo, Piracicaba, Brazil; ${ }^{2}$ Institute of \\ Biological Sciences, São Paulo State University, Rio Claro, Brazil. \\ Email: mbitt@esalq.usp.br
}

Received October $16^{\text {th }}, 2011$; revised November $17^{\text {th }}, 2011$; accepted December $25^{\text {th }}, 2011$

\begin{abstract}
Cyanobacterial blooms have become a worldwide concern due to the production of toxins harmful to humans and animals. In Brazil and worldwide, microcystins are the most frequently found cyanotoxin in water bodies. Four important reservoirs in Brazil's Southeast and Northeast regions were sampled to identify the cyanobacteria community and the occurrence of potential toxin-producing species in the country's public supply reservoirs. A total of 14 taxa were identified, 11 of which are known as potential toxin producers. Potentially toxic cyanobacteria were recorded at concentrations above 20,000 cells $\cdot \mathrm{mL}^{-1}$ in all samples from all four reservoirs, thus requiring microcystin monitoring in drinking water according to Brazilian legislation. Although the sample from Mundaú reservoir showed the highest concentration of microcystins in water, it had one of the lowest values of cells $\cdot \mathrm{mL}^{-1}$, which demonstrates the non-correspondence between these two parameters. This calls into question the existence of a minimum level of potentially toxic cyanobacteria cells to merit the monitoring of microcystins in the treated water from these sources.
\end{abstract}

Keywords: Cyanotoxins; Cylindrospermopsis; Microcystins; Microcystis; Public Water Supply

\section{Introduction}

Several different cyanobacteria species are known for their ability to form blooms and produce toxins [1,2]. Microcystins are hepatotoxic cyclical peptides produced by certain species from genera Microcystis, Planktothrix and Dolichospermum/Anabaena and can cause damage to liver cells and other organs and systems [3].

In Brazil and worldwide, microcystins are the most frequently found cyanotoxins in water bodies [4]. Following a case of acute intoxication and death of patients caused by the presence of microcystins in the water used in a hemodialysis clinic [5], Brazil became the first country to propose specific legislation to control cyanobacteria and cyanotoxins in public water supplies. Brazilian legislation for water supply monitoring to the human population requires monitoring of cyanobacteria cell density in raw water from the source, as well as of treated water for consumption, giving maximum allowed values of microcystins $\left(1 \mu \mathrm{g} \cdot \mathrm{L}^{-1}\right)[6]$.

Bloom events featuring high concentrations of toxins in water supply reservoirs have been reported in different regions of Brazil, especially in the Southeast and Northeast [7-15]. This is due to favorable climate conditions, and particularly to the intense process of enrichment and eutrophication of water bodies, which favors cyanobacteria development [16].

In northeastern Brazil, the bloom problem is further increased by the water regime, which is characterized by pronounced drought periods requiring a large number of reservoirs and long residence times and these factors favor the occurrence of such events [10]. BittencourtOliveira et al. [9] observed the presence of potentially toxic cyanobacteria in 21 of the 27 samples collected at seven reservoirs in the southeast and northeast of Brazil. All samples containing cyanobacteria also featured microcystins and genes involved in producing this toxin.

The objective of this work was to identify potential toxin-producing cyanobacteria at four important reservoirs used for public water supply in Brazil.

\section{Material and Methods}

\subsection{Study Area}

Samplings were carried out at four public water supply reservoirs in Brazil: Billings and Rio Grande in the state of São Paulo (SP), Southeast, and Carpina and Mundaú in the state of Pernambuco (PE), Northeast (Figure 1). The dates and places of the samplings can be found in Table 1. 


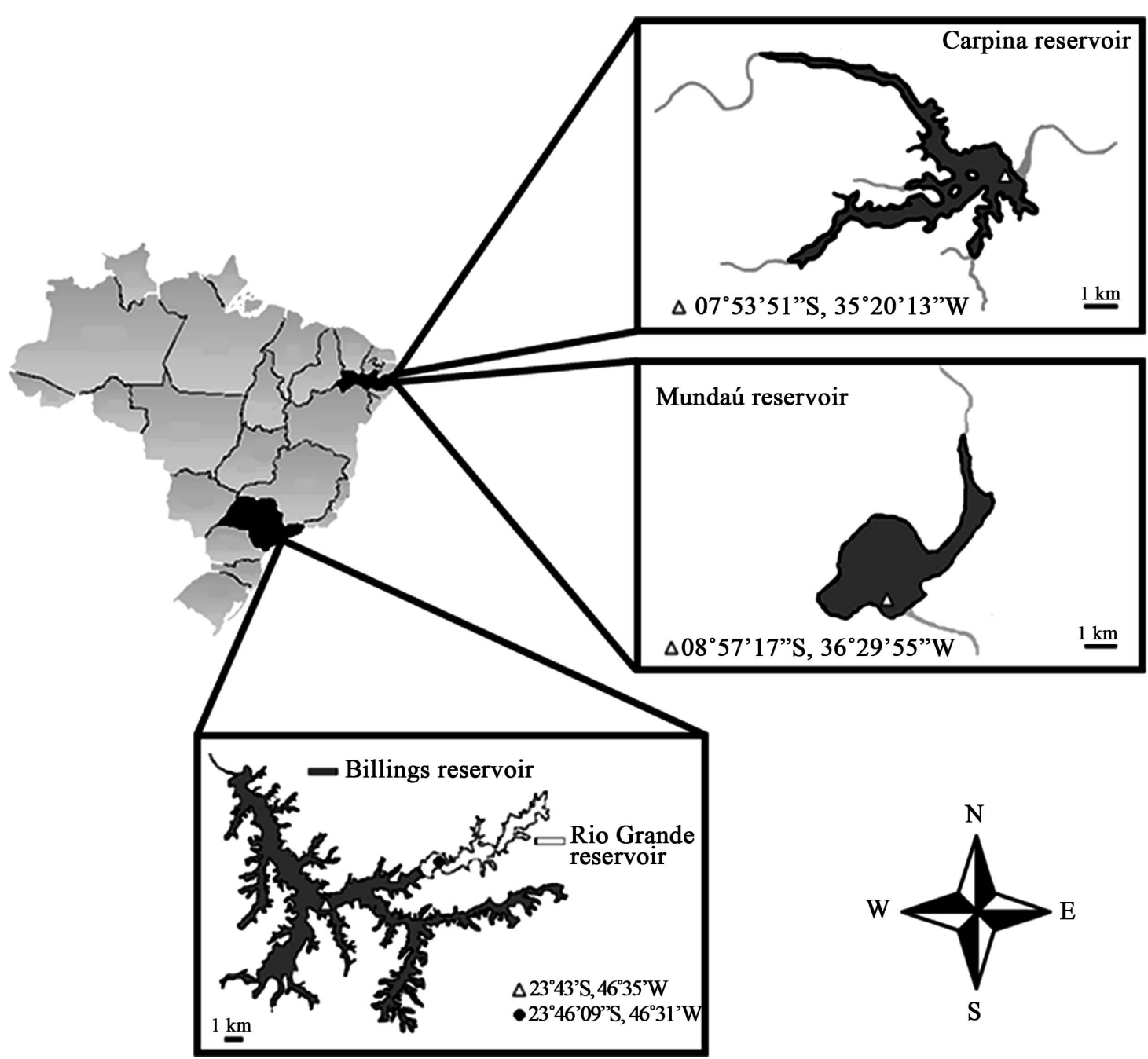

Figure 1. Map of sampling sites. Triangles and circles correspond to collection points with their coordinates.

Table 1. Location and date of collections, sample code, georeferenced coordinates, cell density of the most frequent species and of microcystins, detection of genotypes indicative of toxicity. MC: Microcystin concentration given by HPLC/LC-MS or ELISA. (+/-) presence/absence of genotypes indicative of toxicity (genes mcyA and mcyB). NP: Not performed.

\begin{tabular}{|c|c|c|c|c|c|}
\hline Collection site & Code & Cells $\cdot \mathrm{mL}^{-1}\left(\times 10^{4}\right)$ & Most frequent species & $M C\left(\mu g \cdot L^{-1}\right)^{a}$ & Genes $m c y^{\mathrm{a}}$ \\
\hline Billings, SP & B1 & NP & Cylindrospermopsis raciborskii & 0.59 & + \\
\hline Billings, SP & B2 & $>30$ & Cylindrospermopsis raciborskii & 2.27 & + \\
\hline Billings, SP & B3 & $10-30$ & Cylindrospermopsis raciborskii & 0.43 & + \\
\hline Billings, SP & B4 & $10-30$ & Microcystis panniformis & 1.81 & + \\
\hline Billings, SP & B5 & $10-30$ & Microcystis panniformis & 0.51 & + \\
\hline Rio Grande, SP & R1 & $2-10$ & Dolichospermum flos-aquae & 1.25 & + \\
\hline Mundaú, PE & M1 & $2-10$ & Cylindrospermopsis raciborskii & 223.67 & + \\
\hline Carpina, PE & $\mathrm{C} 1$ & $>30$ & Microcystis panniformis & 1.15 & + \\
\hline Carpina, PE & $\mathrm{C} 2$ & $>30$ & Microcystis panniformis & 0 & + \\
\hline Carpina, PE & $\mathrm{C} 3$ & $>30$ & Microcystis panniformis & 0 & + \\
\hline Carpina, PE & $\mathrm{C} 4$ & $>30$ & Microcystis panniformis & 0.76 & + \\
\hline
\end{tabular}

${ }^{\mathrm{a} B i t t e n c o u r t-O l i v e i r a ~ e t ~ a l . ~[10] . ~}$ 
The study used $25-\mu \mathrm{m}$ mesh subsurface trawl plankton nets and van Dorn bottle to collect samples for qualitative and quantitative analyses, respectively. The samples used for qualitative and quantitative analyses were preserved using Lugol's acetic solution until the sample turned into a slightly brown color, respectively.

The Billings reservoir reaches a maximum water volume of 1.2 billion $\mathrm{m}^{3}$ and receives the flow from two rivers (Tietê and Pinheiros) crossing the city of São Paulo, SP, home to the world's fifth largest population. It has a supply system which transfers raw water to Guarapiranga reservoir, supplying 3.8 million inhabitants. Also in São Paulo, the Rio Grande reservoir supplies nearly 1.6 million people. Mundaú reservoir has a holding capacity of $1,968,600 \mathrm{~m}^{3}$ of water and is subjected to pronounced seasonal climate variation, coastal humid and inland dry. Its drainage basin receives part of the domestic sewage from the city of Garanhuns, PE, which has 150,000 inhabitants, approximately [17]. With a maximum volume of 2.7 million $\mathrm{m}^{3}$, Carpina reservoir is important for irrigation and fishery activities, in addition to its use for public water supply [18].

\subsection{Qualitative and Quantitative Analyses}

The taxonomic identification of cyanobacteria was performed according to specialized literature, using a binocular microscope (Nikon YS100, Japan) with a coupled measuring eyepiece.

Photodocumentation of the different taxa was carried out using a digital system consisting of an optical microscope (Nikon Eclipse E200), with an attached digital camera (Samsung, Japan) and software (Imagelab 2000, Brazil). Aliquots of the samples collected with the Van Dorn bottle were stored in $200 \mathrm{~mL}$ flasks and immediately preserved in Lugol's solution for the subsequent phytoplankton count. Counts were performed using an inverted microscope (Zeiss/Axiovert) following the method described by [19].

\section{Results}

We recorded potentially toxic cyanobacteria at concentrations above 20,000 cells $\cdot \mathrm{mL}^{-1}$ in all samples from all four studied reservoirs (Table 1). A total of 14 taxa were identified, 11 of which are known as potential toxin producers (Table 2) (Figures 2(a)-(h)). Some taxa belonging to orders Nostocales and Oscillatoriales could not be identified at species level due to the absence of heterocysts and akinetes. Billings's reservoir showed a high concentration of cyanobacteria cells and the highest richness of cyanobacteria (9 taxa). Most of the recorded taxa are known as toxin producers (Table 1). At Rio Grande reservoir we found a high number of cells of Dolichospermum flos-aquae Rabenhorst ex Bornet \& Flahault, which is a potential toxin-producing species (Tables 1-2). Mundaú reservoir showed the lowest richness of cyanobacteria, with five taxa belonging to potential toxin-producing genera (Table 2). In this reservoir, the cell density was also one of the lowest $\left(2 \times 10^{4}-10 \times\right.$ $10^{4}$ cells $\left.\cdot \mathrm{mL}^{-1}\right)$.

Table 2. Occurrence of cyanobacteria species present in the samples. (+/-) presence/absence. B1. Billings Feb. 6, 2007 ; B2. Billings Feb. 13, 2007; B3. Billings Feb. 28, 2007; B4. Billings Mar. 6, 2007; B5. Billings Mar. 14, 2007; R1. Rio Grande Mar. 27, 2007; M1. Mundaú Apr. 14, 2007; C1. Carpina Jun. 30, 2007; C2. Carpina Jul. 21, 2007; C3. Carpina Jul. 28, 2007 ; C4. Carpina Aug. 4, 2007. Microcystis aeruginosa (Kützing) Kützing; Microcystis botrys Teiling; Microcystis novacekii (Komárek) Compére; Microcystis panniformis Komárek et al.; Microcystis protocystis Crow; Microcystis wesenbergii Komárek; Dolichospermum flos-aquae (Brébisson ex Bornet \& Flahault) Wacklin et al.; Sphaerospermopsis aphanizomenoides (Forti) Zapomelová et al.; Cylindrospermopsis raciborskii (Woloszynska) Seenayya \& Subba Raju; Arthrospira khannae Drouet \& Strickland; Planktothrix isothrix (Skuja) Komárek \& Komárková; Geitlerinema amphibium Agardh ex Gomont.

\begin{tabular}{|c|c|c|c|c|c|c|c|c|c|c|c|}
\hline \multirow{2}{*}{ Taxa } & \multicolumn{11}{|c|}{ Samples } \\
\hline & B1 & B2 & B3 & B4 & B5 & $\mathbf{R} 1$ & M1 & $\mathrm{C1}$ & $\mathrm{C} 2$ & $\mathrm{C} 3$ & $\mathrm{C} 4$ \\
\hline Microcystis aeruginosa & - & - & + & + & - & - & - & - & - & - & - \\
\hline Microcystis botrys & - & - & - & - & - & + & - & + & + & - & - \\
\hline Microcystis novacekii & + & + & + & + & + & + & + & - & - & - & - \\
\hline Microcystis panniformis & + & + & + & + & + & - & + & + & + & + & + \\
\hline Microcystis protocystis & - & - & + & + & + & - & - & - & - & - & - \\
\hline Microcystis wesenbergii & - & - & + & - & - & - & - & - & - & - & - \\
\hline Cylindrospermopsis raciborskii (straight and coiled) & + & + & + & + & + & + & + & + & + & + & + \\
\hline Dolichospermum flos-aquae & - & - & - & - & - & + & - & - & - & - & - \\
\hline Dolichospermum sp. 1 & - & + & - & + & - & + & - & + & - & - & - \\
\hline Sphaerospermopsis aphanizomenoides & - & - & - & - & - & - & - & + & + & + & + \\
\hline Arthrospira khannae & - & + & - & + & - & - & - & - & - & + & - \\
\hline Geitlerinema amphibium & - & - & - & - & - & - & + & - & - & - & - \\
\hline Planktothrix isothrix & + & + & + & + & + & + & - & + & + & + & + \\
\hline Pseudanabaena sp. 1 & - & - & - & - & - & - & + & - & - & - & - \\
\hline
\end{tabular}




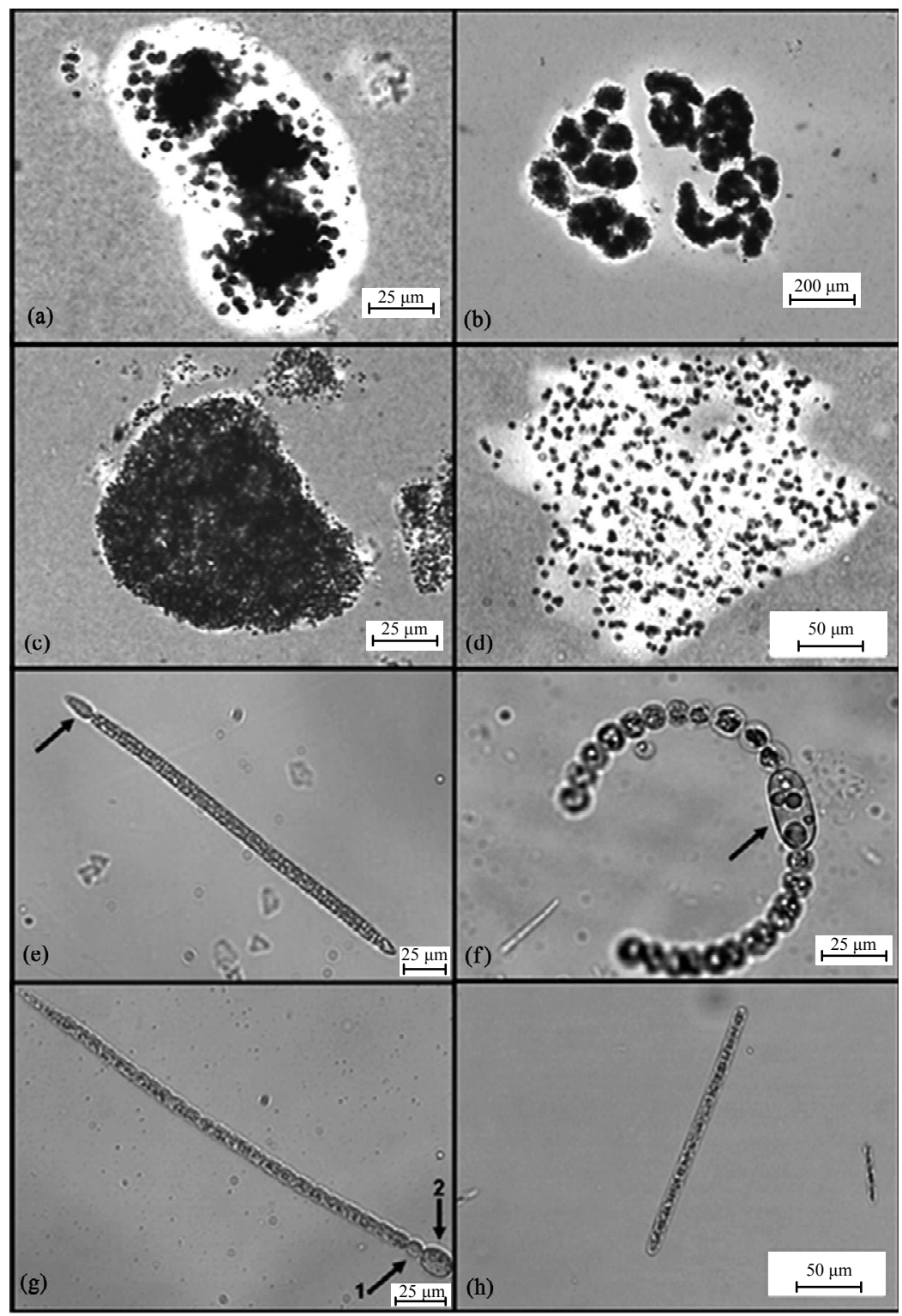

Figure 2. Potential toxin-producing cyanobacteria (a) Microcystis botrys; (b) Microcystis novacekii; (c) Microcystis panniformis; (d) Microcystis protocystis; (e) Cylindrospermopsis raciborskii (straight), arrow: heterocyst; (f) Dolichospermum flos-aquae, Arrow: akinete; (g) Sphaerospermopsis aphanizomenoides, Arrow 1: heterocyst, Arrow 2: akinete.

In Carpina, a bloom of the species Microcystis panniformis Komárek et al. was observed, lasting for four consecutive weeks of sampling. Considering all the samples, among potential toxin-producing genera,

Microcystis, Dolichospermum, Cylindrospermopsis and Planktothrix were the most common. The genus

Microcystis was recorded at all reservoirs and

Planktothrix was not observed only at Mundaú reservoir (Table 2).

\section{Discussion}

This work evaluated four important public water supply reservoirs in the Southeast and Northeast regions of Bra- zil, for which Brazilian legislation requires periodical monitoring of microcystins in treated water [6]. Concentrations above 20,000 cells $\cdot \mathrm{ml}^{-1}$ were recorded at all studied reservoirs. The high number of cyanobacteria cells and the presence of several taxa known as toxin producers found in the samples from Billings reservoir (Table 1) have also been reported by other authors [13, 20]. While evaluating the same samples used in the present work, Bittencourt-Oliveira et al. [10] found concentrations of microcystins ranging from 0.43 to $2.27 \mu \mathrm{g} \cdot \mathrm{L}^{-1}$ (Table 1). Using the PCR technique with primers for genes mcyA and mcyB (part of microcystin operon), those authors identified the presence of genotypes in- 
dicative of toxicity in all samples (Table 1). Others studies also reported the presence of microcystins and saxitoxins in the water of the Billings reservoir $[7,13]$.

The Rio Grande reservoir is an extension of Billings, and was detached from it to improve the quality and quantity of water for public supply [21]. The high number of cells of Dolichospermum flos-aquae (potential toxin-producing species) found in this work, together with the presence of genotypes indicative of toxicity observed by Bittencourt-Oliveira et al. [10] in samples from this reservoir (Table 1), indicates that there was no improvement in water quality with regard to cyanobacteria and cyanotoxins, when compared to the Billings reservoir.

The Mundaú reservoir was the one exhibiting the lowest occurrence of cyanobacteria with taxa potentially toxin producing (Table 2). It has prevailed in this reservoir the high concentration of microcystins (223.67 $\mu \mathrm{g} \cdot \mathrm{L}^{-1}$ ) found in the sample collected at April 14, 2007 (Table 1). Despite the fact that this sample presented the highest concentration among microcystins, this finding does not correlate with its cellular density, one of the lowest showing up in this study $\left(2 \times 10^{4}\right.$ to $10 \times 10^{4}$ células $\left.\cdot \mathrm{mL}^{-1}\right)$. Under this circumstance, it is questionable the framing of microcystins monitoring in treated water to the cellular density of cyanobacteria present in water from sources.

Dominance of Microcystis, a cyanobacteria microcystin-producing, along with Cylindrospermopsis raciborskii (Woloszynska) Seenayya \& Subba Raju, is commonly recorded at Mundaú $[8,10,17]$.

It was observed in Carpina a bloom of the species $M$. panniformis, which extended itself all along the four consecutive sampling weeks. In addition to the

Microcystis bloom observed throughout the sampling period in Carpina, it was also identified the presence of genotypes indicative of toxicity in all samples, as well as the presence of microcystins in the samples collected on June 30 and August 4 (Table 1) [10]. Moura et al. [22] recorded Planktothrix agardhii (Gomont) Anagnostidis \& Komárek as dominant in the phytoplankton community of that reservoir. However, this taxon was not found in the present study.

We observed in the total amount of samples that the main toxin-producing genera, such as Microcystis, Dolichospermum, Cylindrospermopsis and Planktothrix, showed up at the different reservoirs, despite the 2600 $\mathrm{km}$ distance between these bodies of water. The high number of potential toxin-producing cyanobacteria and the presence of microcystins in the water of all studied reservoirs emphasize the need for persistent monitoring of the sampled sites, as they represent important water supply sources in Brazil. The existence of a minimum level of potentially toxic cyanobacteria cells to merit the monitoring of microcystins in drinking water from these sources is there by called into question.

\section{Acknowledgements}

This study was supported by grants from the Brazilian funding agencies FAPESP (State of São Paulo Foundation for the promotion of Research, 2006/03878-3, 2007/ 57338-2) and CNPq (National Council for Research and Development 300794/2004-5).

\section{REFERENCES}

[1] J. F. Briand, S. Jacquet, C. Bernard and J. F. Humbert, "Health Hazards for Terrestrial Vertebrates from Toxic Cyanobacteria in Surface Water Ecosystems," Veterinary Research, Vol. 34, No. 4, 2003, pp. 361-377.

doi:10.1051/vetres:2003019

[2] W. W. Carmichael, "The Toxins of Cyanobacteria," Scientific American, Vol. 270, No. 1, 1994, pp. 78-86. doi:10.1038/scientificamerican0194-78

[3] I. R. Falconer, A. M. Beresford and M. T. Runnegar, "Evidence of Liver Damage by Toxin from a Bloom of the Blue-Green Alga Microcystis aeruginosa," Medicine Journal, Vol. 1, No. 11, 1983, pp. 511-114.

[4] D. R. Figueiredo, U. M. Azeiteiro, S. M. Esteves, F. J. M. Gonçalves and M. J. Pereira, "Microcystin-Producing Blooms a Serious Global Public Health Issue," Ecotoxicology and Environmental Safety, Vol. 59, No. 2, 2004, pp. 151-163. doi:10.1016/j.ecoenv.2004.04.006

[5] E. M. Jochimsen, W. W. Carmichael, J. An, D. M. Cardo, S. T. Cookson, C. E. M. Holmes, B. C. Antunes, D. A. Melo Filho, T. M. Lyra, V. S. T. Barreto, S. M. F. O. Azevedo and W. R. Jarvis, "Liver Failure and Death After Exposure to Microcystin at a Hemodialysis Center in Brazil," The New England Journal of Medicine, Vol. 338, No. 13, 1998, pp. 873-878. doi:10.1056/NEJM199803263381304

[6] Brazil Health Minister, Regulation N. 518/2004, "Guidelines for Drinking Water Quality," Official Law Reports, 2004, p. 266.

http://www.abes-sp.org.br/arquivos/portaria_518_2004.p df

[7] F. M. A. Anjos, M. C. Bittencourt-Oliveira, M. P. Zajac, S. Hiller, B. Christian, K. Erler, K. Luckas, and E. Pinto, "Detection of Harmful Cyanobacteria and Their Toxins by Both PCR Amplification and LC-MS during a Bloom Event," Toxicon, Vol. 48, No. 3, 2006, pp. 239-245.

doi:10.1016/j.toxicon.2006.05.006

[8] M. C. Bittencourt-Oliveira, D. M. S. Santos and N. A. Moura, "Toxic Cyanobacteria in Reservoirs in Northeastern Brazil: Detection Using a Molecular Method," Brazilian Journal of Biology, Vol. 70, No. 4, 2010, pp. 10051010. doi:10.1590/S1519-69842010000500012

[9] M. C. Bittencourt-Oliveira, V. Piccin-Santos and S. Gouvêa-Barros, "Microcystin-Producing Genotypes from Cyanobacteria in Brazilian Reservoirs," Environmental Toxicology, Early View (Online Version of Record Published 
before Inclusion in an Issue). doi:10.1002/tox.20659 2010

[10] M. C. Bittencourt-Oliveira, V. Piccin-Santos, P. Kujbida and A. N. Moura, "Cylindrospermopsin in Water Supply Reservoirs in Brazil Determined by Immunochemical and Molecular Methods," Journal of Water Resource and Protection, Vol. 3, No. 6, 2011, pp. 349-355. doi:10.4236/jwarp.2011.36044

[11] M. Bouvy, D. Falcão, M. Marinho, M. Pagano and A. Moura, "Occurrence of Cylindrospermopsis (Cyanobacteria) in 39 Brazilian Tropical Reservoirs during the 1998 Drought," Aquatic Microbial Ecology, Vol. 23, No. 5, 2000, pp. 13-27. doi:10.3354/ame023013

[12] I. A. S. Costa, S. M. F. O. Azevedo, P. A. C. Senna, R. R. Bernardo, S. M. Costa and N. T. Chellappa, "Occurrence of Toxin-Producing Cyanobacteria Blooms in a Brazilian Semiarid Reservoir," Brazilian Journal of Biology, Vol. 66, No. 1B, 2006, pp. 211-219. doi:10.1590/S1519-69842006000200005

[13] V. Moschini-Carlos, S. Bortoli, E. Pinto, P. Y. Nishimura, L. G. Freitas, M. L. M. Pompêo and F. Dörr, "Cyanobacteria and Cyanotoxin in the Billings Reservoir (São Paulo, SP, Brazil)," Limnetica, Vol. 28, No. 2, 2009, pp. 273282.

[14] R. B. Sotero-Santos, C. R. S. E. Silva, N. F. Verani, K. O. Nonaka and O. Rocha, "Toxicity of a Cyanobacteria Bloom in Barra Bonita Reservoir (Middle Tietê River, São Paulo, Brazil)," Ecotoxicology and Environmental Safety, Vol. 64, No. 2, 2006, pp. 163-170. doi:10.1016/j.ecoenv.2005.03.011

[15] R. B. Sotero-Santos, G. E. Carvalho, M. J. DellamanoOliveira and O. Rocha, "Occurrence and Toxicity of an Anabaena Bloom in a Tropical Reservoir (Southeast Brazil)," Harmful Algae, Vol. 7, No. 5, 2008, pp. 590-598. doi:10.1016/j.hal.2007.12.017

[16] A. Rantala, P. Rajaniemi-Wacklin, C. Lyra, L. Lepisto, J. Rintala, J. Mankiewicz-Boczek and K. Sivonen, "Detection of Microcystin-Producing Cyanobacteria in Finnish
Lakes with Genus-Specific Microcystin Synthetase Gene E (mcyE) PCR and Associations with Environmental Factors," Applied and Environmental Microbiology, Vol. 72, No. 9, 2006, pp. 6101-6110. doi:10.1128/AEM.01058-06

[17] M. C. Bittencourt-Oliveira, A. N. Moura, T. C. Hereman and E. W. Dantas, "Increase in Straight and Coiled Cylindrospermopsis raciborskii (Cyanobacteria) Populations Under Conditions of Thermal De-Stratification in a Shallow Tropical Reservoir," Journal of Water Resource and Protection, Vol. 3, No. 4, 2011, pp. 245-252. doi:10.4236/jwarp.2011.34031

[18] A. N. Moura, E. W. Dantas, H. S. B. Oliveira and M. C. Bittencourt-Oliveira, "Vertical and Temporal Dynamics of Cyanobacteria in the Carpina Potable Water Reservoir in Northeastern Brazil," Brazilian Journal of Biology, Vol. 71, No. 2, 2011, pp. 1-9. doi:10.1590/S1519-69842011000300015

[19] H. Utermöhl, "Zur Vervollkommnung der Quantitativen Phytoplankton-Methodik," Mitteilungen Internationale Vereiningung fuer Theoretische und Angewandte Limnologie, Vol. 9, 1958, pp. 1-38.

[20] L. R. Carvalho, C. L. Sant'Anna, M. P. Gemelgo and M. T. P. Azevedo, "Cyanobacterial Occurrence and Detection of Microcystin by Planar Chromatography in Surface Water of Billings and Guarapiranga Reservoirs, SP, Brazil," Revista Brasileira de Botânica, Vol. 30, No. 1, 2007, pp. 141-148.

[21] Z. Beyruth and H. A. S. Pereira, "The Isolation of Rio Grande from Billings Reservoir, São Paulo, Brazil: Effects on the Phytoplankton," Boletim do Instituto de Pesca, Vol. 28, No. 2, 2002, pp. 111-123.

[22] A. N. Moura, E. W. Dantas and M. C. BittencourtOliveira, "Structure of the Phytoplankton in a Water Sup ply System in the State of Pernambuco, Brazil," Brazilian Archives of Biology and Technology, Vol. 50, No. 4, 2007, pp. 645-654. doi:10.1590/S1516-89132007000400010 